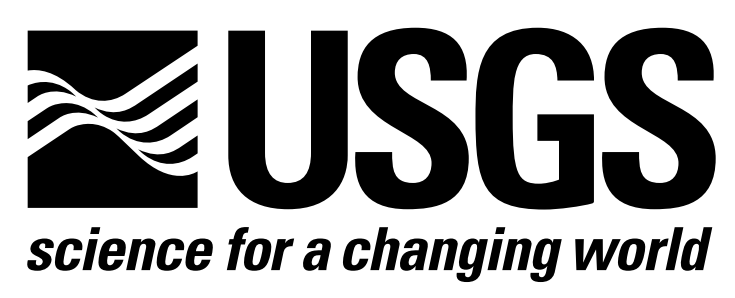

\title{
BASE FLOW AND GROUND WATER IN UPPER SWEETWATER VALLEY, TENNESSEE
}

R.D. Evaldi and J.G. Lewis

\section{U.S. GEOLOGICAL SURVEY}

Water-Resources Investigations 83-4068

Prepared in cooperation with the

Board of Public Utilities

Sweetwater, Tennessee 


\section{UNITED STATES DEPARTMENT OF THE INTERIOR JAMES G. WATT, Secretary GEOLOGICAL SURVEY \\ Dallas L. Peck, Director}

For additional information write to:

District Chief U.S. Geological Survey A-413 Federal Bldg. A-413 Federal Bldg. Nashville, TN 37203
Copies of this report can be purchased from:

Open-File Services Section U.S. Geological Survey Western Geological Survey Box 25425, Federal Center Lakewood, CO 80225

( Te lephone: (303 234-5888) 
Abstract . . . . . . . . . . . . . . . . . . . 1

Introduction ... . . . . . . . . . . . . . . . . 2

Hydrogeologic framework . . . . . . . . . . . . . . 2

Physiography .. . . . . . . . . . . . . . . . 2

Hy drogeology . . . . . . . . . . . . . . . . . 2

Analysis of streamflow records . . . . . . . . . . . . 8

Discharge data . . . . . . . . . . . . . . 8

Lowf low estimates . . . . . . . . . . . . . 8

Water budget . . . . . . . . . . . . . . . . 11

Inventory of springs, wells, and water quality . . . . . . 11

Springs . . . . . . . . . . . . . . . . . . . 11

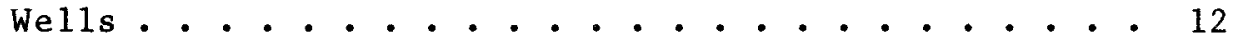

Water quality . . . . . . . . . . . . . . . 12

Base-flow analysis . . . . . . . . . . . . . . . . 13

Base-flow measurements . . . . . . . . . . . . 13

Areas of surplus and deficient flow . . . . . . . . 16

Concepts of groundwater flow . . . . . . . . . . . . 21

Previous investigations . . . . . . . . . . . . . 21

Upper Sweetwater Valley system . . . . . . . . . . 21

Potential sources of water supply . . . . . . . . . . . 24

Site selection . . . . . . . . . . . . . . 24

Resource protection . . . . . . . . . . . . . 27

Summary and conclusions . . . . . . . . . . . . . . 27

References cited . . . . . . . . . . . . . . . 30

\section{ILLUSTRATIONS}

Figure 1. Location of the upper Sweetwater Valley study-area and relation to physiographic subdivisions of the Appalachian Mountains . . . 3

2. Geologic map and cross section of upper Sweetwater Valley, Tennessee....... 5

3. Drainage network of upper Sweetwater Creek showing stream gage and major spring locations . 9

4. Low base-flow measurement site locations, and change in water discharge between sites October 15-20, 1981

5. Low base-flow measurement site locations, and change in water discharge between sites February 23-24, 1982 .......... . 20 


\section{ILLUSTRATIONS}

Page

6. Areas of surplus and deficient flows in upper

Sweetwater Valley Oct. 15-20, 1981 . . . . . 22

7. Areas of surplus and deficient flows in upper

Sweetwater Valley Feb. 23, 24, 1982 . . . . 23

8. Theoretical ground water flow network of upper Sweetwater Valley Feb. 23, 24, 1982 . . 25

9. Potential ground-water supply areas in upper

Sweetwater Valley .......... 26

10. Locations of sinkholes and linear features

from aerial photographic interpretation . . . 28

\section{TABLES}

Table 1. Description and water-bearing characteristics of formations in upper Sweetwater Valley,

Tennessee............... 6

2. Streamflow of Sweetwater Creek ....... 10

3. Low-flow frequency estimates of Sweetwater

Creek below Sweetwater, Tennessee... . . . 10

4. Estimated 1980 water budget of upper Sweetwater

Valley above Sweetwater Creek mile 17.6 . . . 12

5. Description of wells in upper Sweetwater Valley with maximum reported yield from indicated geologic formation .......... . 13

6. Range in water-quality parameters from Sweetwater Creek, for samples obtained October 1968 to

September 1972 . . . . . . . . . . . . . 14

7. Low base-flow data . . . . . . . . . 15

8. High base-flow data. . . . . . . . . . 18 
FACTORS FOR CONVERTING INCH-POUND UNITS TO

INTERNATIONAL SYSTEM OF UNITS (SI)

Mu1tip1y

cubic foot per second
$\left(\mathrm{ft}^{3} / \mathrm{s}\right)$

ft (foot)

inch (in)

square mile $\left(\mathrm{mi}^{2}\right)$

gallon per minute (gal/min)

gallon per minute per foot [( $\mathrm{gal} / \mathrm{min}) / \mathrm{ft}]$ by

To obtain

$0.02832 \quad$ cubic meter per second
$\left(\mathrm{m}^{3} / \mathrm{s}\right)$

0.3048 meter $(\mathrm{m})$

25.4

millimeter $(\mathrm{mm})$

2.590

square kilometer $\left(\mathrm{km}^{2}\right)$

0.06308

cubic meter per second $\left(\mathrm{m}^{3} / \mathrm{s}\right)$

0.2070

cubic meter per second per meter $\left[\left(\mathrm{m}^{3} / \mathrm{s}\right) / \mathrm{m}\right]$ 


\title{
Base Flow and Ground Water in Upper Sweetwater Valley, Tennessee
}

\author{
by
}

\author{
Ronald D. Evaldi and James G. Lewis
}

\begin{abstract}
The upper Sweetwater Valley area has a flow system with complex interaction between surface and ground water. A water budget study indicated that during dry years approximately three-fourths of the annual flow to Sweetwater Creek may be derived from ground-water sources. Hydrograph analysis showed seasonal variation of recharge to the ground water flow system. Streamflow records were analyzed to estimate the frequency of low flow of Sweetwater Creek at river mile 16.7, and indicated the lowest average flow for 1 day in 20 years to be about 5.1 cubic feet per second. Two periods of base-flow measurements of Sweetwater Creek identified channel reaches with significant gains and losses of streamflow.

Base flow measurements also showed interbasin transfer of water among sub-basins of the valley. Major flow surpluses were associated with areas in which the majority of flow originated at a spring. Topographically low areas adjacent to the main stem of Sweetwater Creek generally have surplus flow. Topographically higher areas generally have deficient surface outflow unless significant spring flow occurs in the basin.

Ground-water recharge occurs by water draining into sinkholes, faults, and fractures. Ground-water flow is regionally diffused across formation strikes from the topographically low areas unless the water is exposed to highly permeable formations or impervious formations. Ground water infiltrates the highly permeable formations and flows along strike. Ground water encountering impervious formations may discharge at small springs at the contact, or may reroute along the contact if the upgradient rock is sufficiently permeable or has well developed secondary porosity. Groundwater discharges to streams at innumerable seeps and at a few large springs. Areas of ground-water flow up-gradient of large springs are hypothesized as likely areas of significant ground-water reservoirs.
\end{abstract}




\section{INTRODUCTION}

This report is the third in a series by the U.S. Geological Survey whose aim is to gain better knowledge of ground-water flow and groundwater-surface-water relations in the folded and faulted Valley and Ridge province of Tennessee. The others were studies of the Dandridge area by Hollyday and Goddard (1979) and of Savannah Valley by Rima (1974). The objective of the upper Sweetwater Valley study was to determine base streamflow and ground water availability and to develop concepts of groundwater occurrence and movement.

The study was restricted in general to the $33 \mathrm{mi}^{2}$ of the upper sweetwater Creek Valley, an area within 4 miles of the city of Sweetwater that included parts of Loudon, McMinn, and Monroe Counties (fig. 1). The 1-year study began in the fall of 1981 and included well and spring inventories, base-flow stream measurements, study of aerial photography and geologic data, and analyses of streamflow data.

The authors thank Lewis W. Roach, General Manager, Board of Public Utilities, City of Sweetwater, for his cooperation and support of this study. Frank Perchalski, Donald Malone, and Daniel Sapp, of TVA, Mapping Services Branch, provided the expertise for aerial photograph interpretation and graphics preparation.

\section{HYDROGEOLOGIC FRAMEWORK}

\section{Physiography}

Upper Sweetwater Valley is in the Valley and Ridge physiographic province (fig. 1). The Valley and Ridge province is characterized by parallel northeast-trending ridges and valleys (Sun and others, 1963). The average width of the province is about $40 \mathrm{miles}$ in the study area. It is a region of complex geologic structure where the topography is controlled by faults and folds. Local topographic relief consists of ridges underlain by resistant sandstone or cherty 1 imestone and dolomite, and valleys underlain by shale and soluble limestone. Sinkholes are numerous and overlapping sinkholes or 1 arge areas with interior drainage are common.

Major thrust faults have caused a general repetition of formations resulting in a repeating sequence of prominent ridges and valleys from northwest to southeast. The contacts between formations strike northeast and the beds dip to the southeast. The Knoxville thrust fault crosses the study area from northeast to southwest. The area is drained by sweetwater Creek which flows northeast.

\section{Hydrogeology}

Sweetwater Valley is underlain by a folded and faulted sequence of approximately 5,000 feet of dolomite, limestone, and shale that range in 


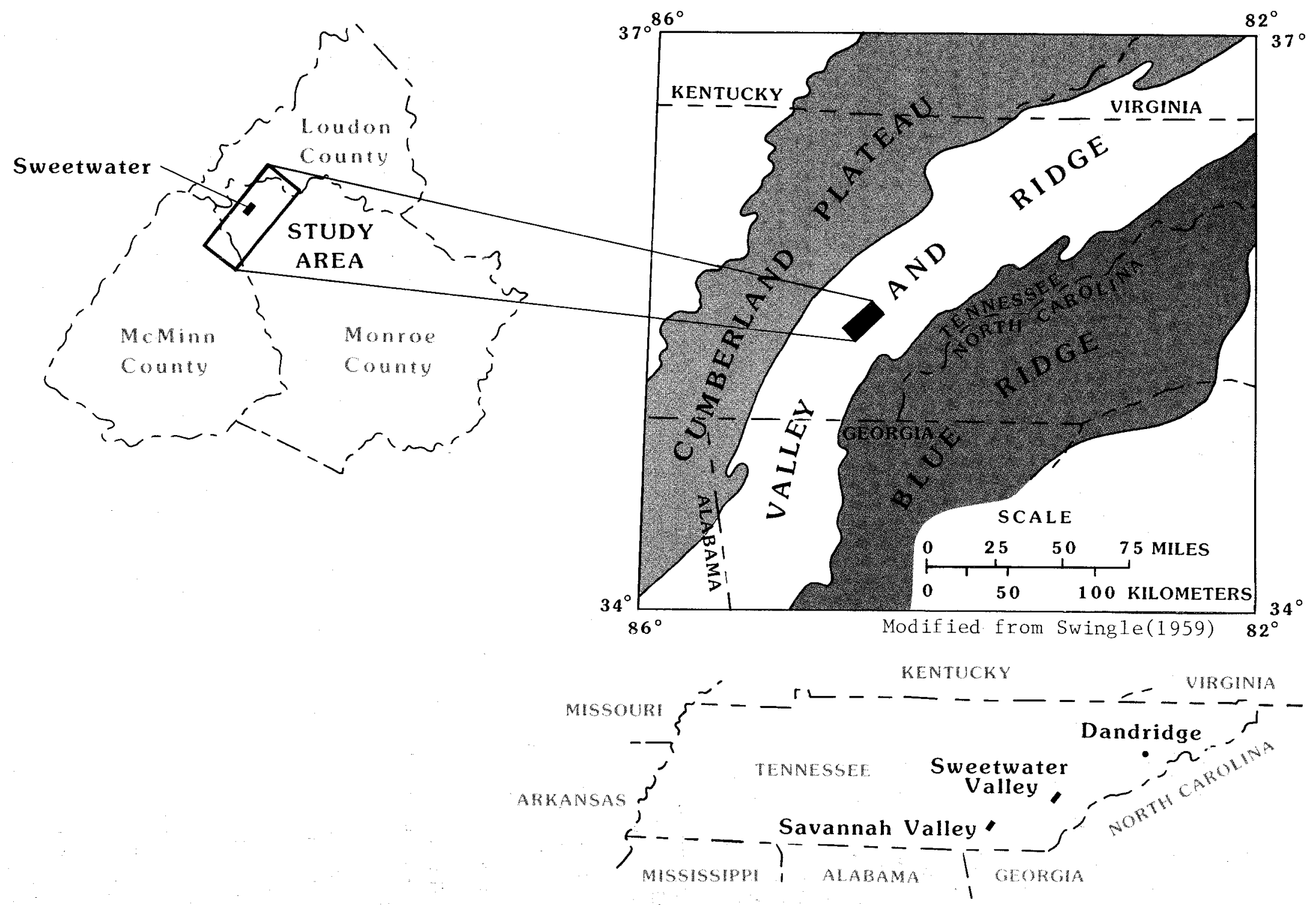

Figure 1.--Location of the upper Sweetwater Valley study area and relation to physiographic subdivisions of the Appalachian Mountains. 
age from Middle Cambrian through Middle Ordovician. The distribution of each formation is shown in figure 2. Bedrock exposures in Sweetwater Valley are mostly small and widely scattered. Almost everywhere the bedrock is covered with weathered rock, slope wash, and soil. Geologic descriptions of the formations in Sweetwater Valley and the water-bearing characteristics are listed in table 1 . Discussions of individual formations are excerpted from reports by Hollyday and Goddard (1979) and Swingle (1959). The hydrologic characterisitics of each formation vary with chemical composition, texture, structure, topographic setting, and degree of weathering.

Weathered material, or residuum, is the most widespread unconsolidated formation in the area. The infiltration rate of the soil forned on the residuum in the Sweetwater area is generally 0.6 to 2.0 inches per hour (Hal1 and others, 1981). Residuum that contains large amounts of rock fragments has a higher permeability than that composed mostly of clay, and will yield and transmit larger quantities of water. Residuum from formations of the Knox Group, such as Copper Ridge Dolomite and Longview Dolomite (former usage), normally yields as much as $5 \mathrm{gal} / \mathrm{min}$ of water to wells. Residuum with less rock fragments, such as that above the Kingsport Formation and Mascot Dolomite (both of former usage), yields lesser quantities (Swingle, 1959).

Slope wash, or colluvium, is abundant but not as widespread as residuum in the area. Water-bearing properties of the colluvium are generally the same as those of the residuum.

Stream deposits, or alluvium, are composed principally of clay, silt, and grave 1-size rock fragments. The rock fragments occur at various depths in the alluvium, unlike those in the residuum which occur near the top of bedrock. The spaces between rock fragments are filled with silt and clay of low permeability which makes the alluvium a poor aquifer.

The limestone was formed from deposits of calcareous mud, fragments of the skeletons of marine organisms, and minor amounts of quartz sand grains. These deposits were solidified by heat and pressure over a period of many years. Some limestones have been recrystallized; rocks that were composed principally of calcite have been replaced by dolomite. These rocks have few pores or primary openings in which water can occur or move.

Secondary openings, formed after the sediments were solidified and recrystallized, occur in the rocks along bedding planes, joints, and numerous fractures in the rocks. Many of these secondary openings have been enlarged by solution along the walls of the openings. These solution formed openings give the dense rock secondary porosity and permeability in which water can occur or move. However, the frequency and size of these openings probably decrease with depth below land surface.

Formations that behave as structurally competent units, such as the Copper Ridge Dolomite, are brittle and tend to fracture cleanly when stressed. The fractures thus produced are numerous and closely spaced, 


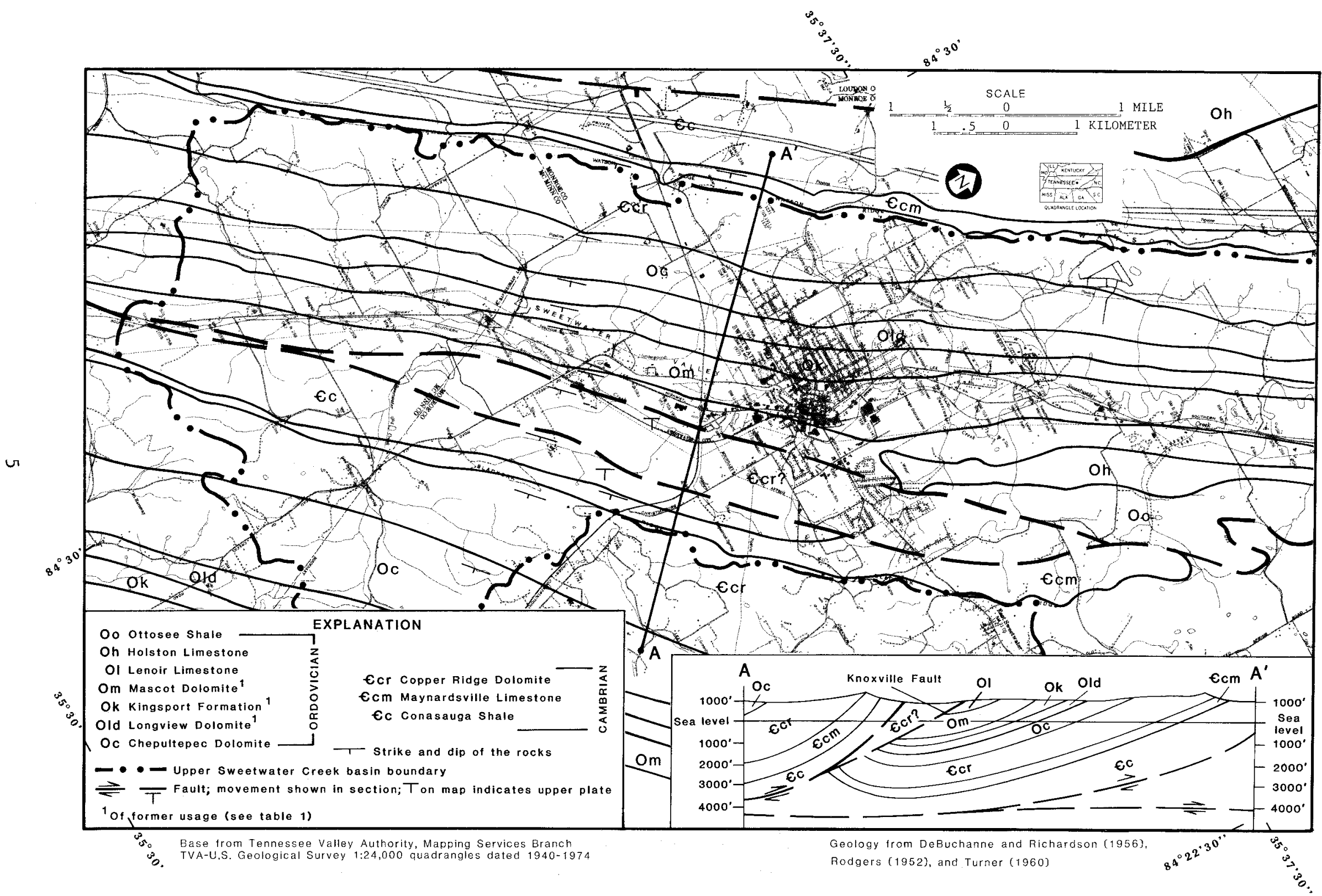

Figure 2.--Geologic map and cross section of upper Sweetwater Valley, Tennessee. 
Table 1.--Description and water-bearing characateristics of formations in upper Sweetwater Valley, Tennessee

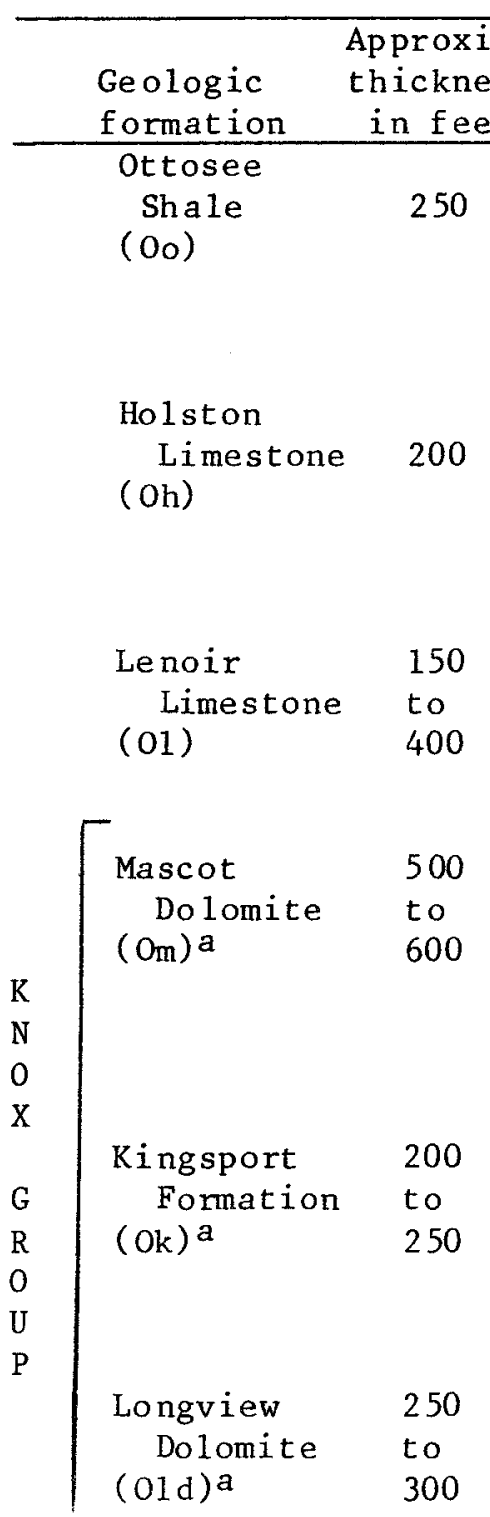

Physical character shale and very shaley 1 imestone; lenses of blue and red crystalline 1 imestone present in shale.

Red, coarsely crystalline limestone ("marble"). Quartzose at top; 1 ayers of blue, medium to finely crystalline limestone at bottom. Some very cherty, blue, aphanitic limestone.

Dark, bluish-weathering, clayey and nodular limestone.

Siliceous and cherty, medium darkgray, cryptocrystalline dolomite. May contain chert, some

cryptocrystalline 1 imestone, and some sandstone.

Dolomite that is either white or 1 ight gray; we11-bedded to massive with a few thin 1 ayers of sandstone or 1 imestone; basal 50 feet all bluish-weathering 1 imestone.

Gray, wel1-bedded dolomite with a few layers of bluish-weathering limestone; contains massive chert.
Water-bearing characteristics

Water occurs in joints, faults, bedding planes, and in solution channels in limestone lenses. Smaller yields and shallower wells than in limestone formations.

Water occurs in fractures and solution openings in coarse crystalline limestone.

Very 1 imited in areal extent. In east Tennessee, 3 of 8 springs inventoried in Lenoir Limestone flow at least $450 \mathrm{gal} / \mathrm{min}$.

In general, water occurs in joints and bedding-plane solution openings. Yields small to large supplies to wel1s. In east Tennessee, 11 of 37 springs inventoried in Mascot Dolomite flow at least $450 \mathrm{gal} / \mathrm{min}$.

In east Tennessee, 2 out of 8 springs inventoried in the Kingsport Formation flow at least $450 \mathrm{ga} 1 / \mathrm{min}$.

Water occurs in solution openings. 
Table 1.--Description and water-bearing characateristics of formations in upper Sweetwater Valley, Tennessee--Continued

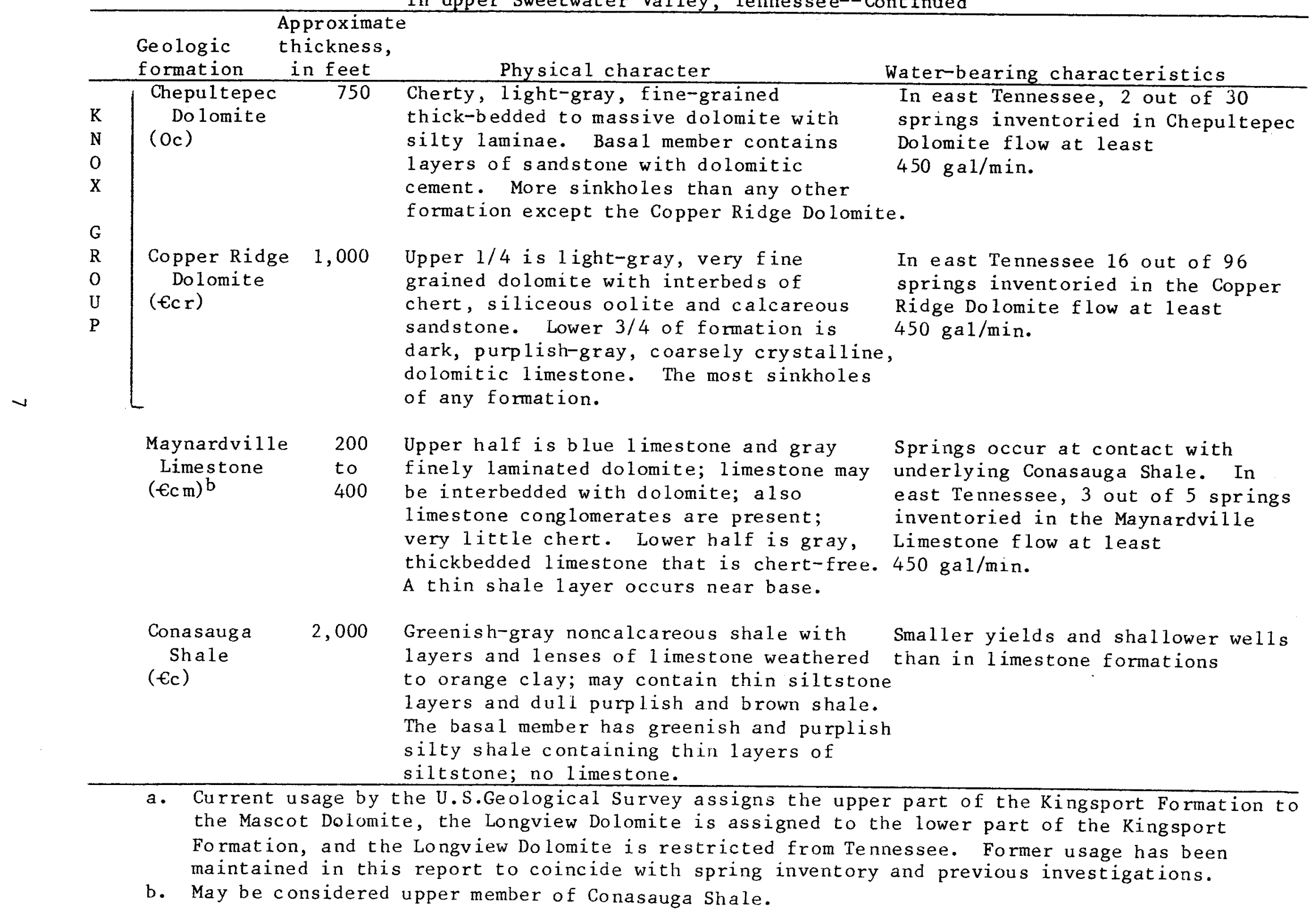


and provide passages for the flow of water. Formations such as the Lenoir Limestone and Conasauga Shale behave as structurally incompetent units and deform more or less plastically when stressed. The fractures produced in such rocks are few and provide limited passageways for water.

Water occurs in secondary openings in calcareous shale containing limestone lenses, such as the Ottosee Shale and upper part of the Conasauga Shale, in joints, faults, and along bedding planes and solution channels. The limestone lenses are thin and relatively rare, and the water-carrying openings are small. The shale tends to fold under stress rather than fracture, and the openings through which the water can move are less numerous than in limestone formations. Water occurs in noncalcareous shale, such as the Conasauga Shale, in much the same manner as in the calcareous group. However, the weathering process does not appreciably increase storage capacity and permeability.

\section{ANALYSIS OF STREAMFLOW RECORDS}

Streamflow records are available for Sweetwater Creek, which is the surface drainage system of the study area. The streamflow records were analyzed to estimate low-flow frequency of Sweetwater Creek and a water budget for 1980. Figure 3 shows the drainage network of upper sweetwater Creek and locations of the stream gaging stations and major springs in the study area.

\section{Discharge Data}

The flow of Sweetwater Creek was gaged August 1964 to September 1981 by TVA. The gage was $2.9 \mathrm{miles}$ northeast of downtown Sweetwater at river mile 16.7 (fig. 3) from August 1964 to April 1970. The gage was relocated May 1970 to a site 2.0 miles northeast of downtown Sweetwater at river mile 17.6 (fig. 3). The drainage area at river mile 16.7 is $28.2 \mathrm{mi}^{2}$, and $26.4 \mathrm{mi}^{2}$ at river mile 17.6 . The annual maximum, minimum, and mean of the daily mean discharges are 1 isted in table 2. The average discharge for $1965-80$ is $50.2 \mathrm{ft}^{3} / \mathrm{s}$. The streamflow was probably affected during low flow by releases or withdrawals of several industries, and the city of Sweetwater filtration plant (river mile 21.8, fig. 3) and sewage disposal plant (river mile 19.6, fig. 3).

\section{Low-Flow Estimates}

Streamflow data for Sweetwater Creek below Sweetwater were analyzed to estimate the frequency of low-flow of the creek (table 3). Because only 11 years of data are available, the low-flow discharges for the corresponding recurrence intervals 1 isted in table 3 should be considered approximations. Those values are expected to change with the collection of additional discharge data at the site. 


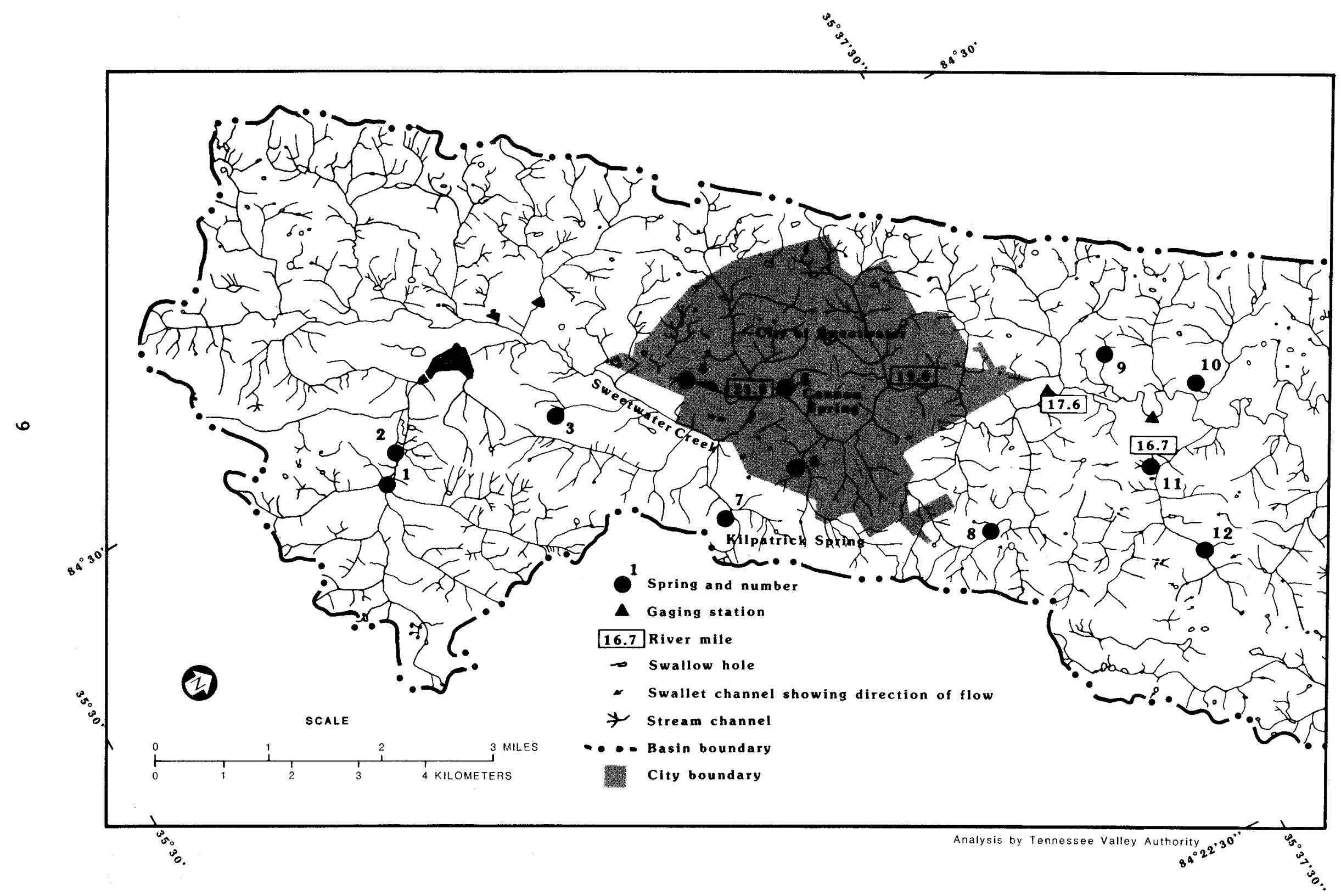

Figure 3.--Drainage network of upper Sweetwater Creek showing major spring locations. 
Table 2.--Streamflow of Sweetwater Creek

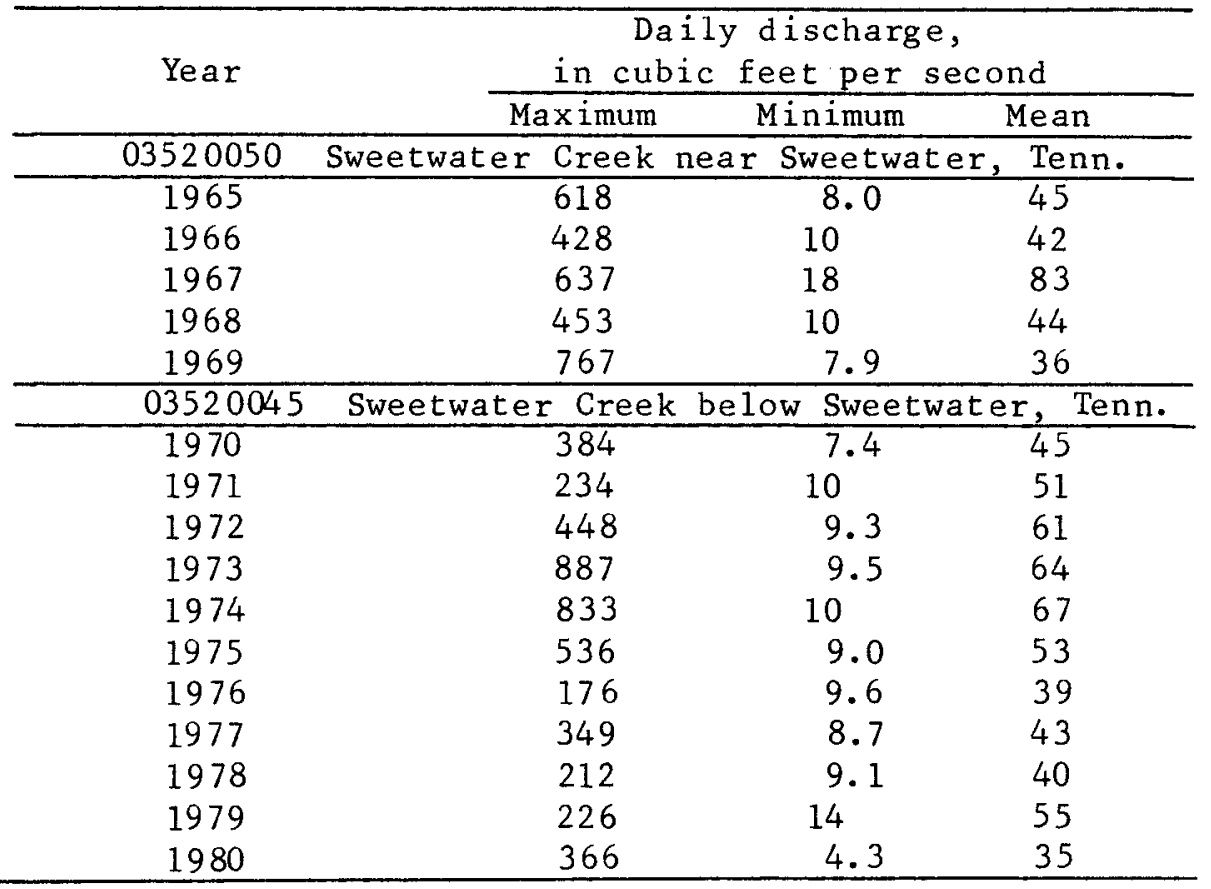

Table 3.--Low flow frequency estimates of Sweetwater Creek below Sweetwater, Tennessee

\begin{tabular}{ccccc}
\hline $\begin{array}{c}\text { Number of } \\
\text { consecutive } \\
\text { days }\end{array}$ & \multicolumn{4}{c}{$\begin{array}{l}\text { oowest average flow, in cubic feet per second } \\
\text { for recurrence interval indicated, in years }\end{array}$} \\
\cline { 2 - 5 } & 2 & 5 & 10 & 20 \\
\hline 1 & 9.5 & 7.3 & 6.1 & 5.1 \\
3 & 9.9 & 7.7 & 6.4 & 5.4 \\
7 & 10 & 8.0 & 6.7 & 5.7 \\
14 & 11 & 8.3 & 7.0 & 6.0 \\
\hline
\end{tabular}

The city of Sweetwater obtains most of its water from Sweetwater Creek at river mile 21.8 ( $\mathrm{fig}$. 3). The creek at that point has a drainage area of $17.1 \mathrm{mi}^{2}$. The Sweetwater Creek gaging station is 1 ocated $4.2 \mathrm{miles}$ below the city filtration plant and the gage records do not directly represent water availability at the filtration plant. The gage is 2.0 miles downstream of the sewage treatment plant and thus measures most of the water utilized by the city. However, the lowest daily streamflow (4.3 $\mathrm{ft}^{3} / \mathrm{s}$ ) for the period of record at the gage occurred during the summer of 1980 when the Sweetwater Utility District reported mild water-supply problems. The recurrence frequency suggests that the city may have a water-supply problem, at current usage rates, less frequently than once in 20 years. 


\section{Water Budget}

Streamflow is maintained by discharge from ground-water sources after a 11 water (overland flow) has drained off the land surface following precipitation. Streamflow from ground-water sources is referred to as base flow. The source of this water is from storage in the ground-water aquifers. In many ways, the ground-water reservoir is analogous to a surface-water impoundment. For example, on an annual or long-term basis, inflow to and outflow from an impoundment are approximately equal. The impoundment provides temporary storage to even out variations in streamflow throughout the year. Likewise, the ground-water reservoir stores water during wet periods of the year and releases it gradually throughout the year.

Because ground-water discharge provides the base flow of streams, surface-water hydrographs can be analyzed to estimate recharge to the ground-water system from individual storms and to estimate ground-water evapotranspiration. The methods are described in reports by Rorabaugh (1964) and Daniel (1976). Results of analyses of hydrographs for Sweetwater Creek below Sweetwater for 1980, a dry year in which the minimum recorded flow occurred, are given in table 4. Some base flow in January was derived from recharge during December 1979. These analyses showed that approximately three-fourths of the annual flow of Sweetwater Creek in 1980 was derived from ground-water sources.

The total runoff of Sweetwater Creek in 1980 was compared to the totals for Tennessee River stations above and below the Sweetwater Creek confluence. The runoff from Sweetwater Creek is considered to agree reasonably with the Tennessee River stations and implies that ground-water underf low must be insignificant:

03497000 Tennessee River at Knoxville $=18.2$ inches.

03520045 Sweetwater Creek below Sweetwater $=18.1$ inches.

03543005 Tennessee River at Watts Bar Dam $=20.6$ inches.

\section{INVENTORY OF SPRINGS, WELLS, AND WATER QUALITY}

\section{Springs}

A spring is a natural discharge of ground water. The rate of discharge from a spring fluctuates in response to changes in the amount of ground water available above spring level. In the study area, the greatest annual flow from a spring generally occurs during the winter or early spring when water levels are highest following winter recharge.

Springs are important sources of water in Sweetwater Valley. They occur throughout the area under diverse topographic and geologic conditions. The water supply for the city of Sweetwater is augmented from Cannon spring (spring no. 5, fig. 3). Water from springs is also used for crop irrigation and for livestock watering. Springs feed Sweetwater Creek, but the amounts of water supplies obtained directly or indirectly from springs are unknown. 
Table 4.--Estimated 1980 water budget of upper Sweetwater Valley above Sweetwater Creek mile 17.6. (Expressed as the depth to which the surface drainage area $\left(26.4 \mathrm{mi}^{2}\right)$ would be uniformly covered)

\begin{tabular}{|c|c|c|c|c|}
\hline \multirow[b]{2}{*}{ Month } & \multicolumn{4}{|c|}{1980 Monthly calculations, in inches } \\
\hline & Precipitationa & Streamf low ${ }^{b}$ & $\begin{array}{l}\text { Recharge to } \\
\text { saturation } \\
\text { zone }\end{array}$ & $\begin{array}{l}\text { Losses to } \\
\text { aeration } \\
\text { zone }\end{array}$ \\
\hline January & 6.1 & 2.7 & 4.0 & 0 \\
\hline February & 2.0 & 2.1 & 1.2 & 0 \\
\hline March & 10.9 & 5.2 & 4.1 & 0 \\
\hline April & 4.1 & 3.1 & 1.5 & 0 \\
\hline May & 3.7 & 1.6 & .9 & 0 \\
\hline June & 1.6 & .9 & .2 & 0 \\
\hline Ju 1y & 3.2 & .4 & .1 & .1 \\
\hline August & 4.6 & .2 & .3 & .1 \\
\hline September & 1.3 & .3 & .3 & 0 \\
\hline October & 3.2 & .4 & .2 & 0 \\
\hline November & 4.7 & .6 & .7 & 0 \\
\hline December & 1.3 & .6 & .5 & 0 \\
\hline
\end{tabular}

1980 SUMMARY: Precipitation, 46.7 inches; stream discharge, 18.1 inches; baseflowc, 13.8 inches (76 percent); overland runoff, 4.3 inches (24 percent); ground-water underflow, 0 ; and evapotranspiration, 28.6 inches.

a Average of Athens and Lenoir City reports (National Oceanic and Atmospheric Administration, 1980).

$b$ Includes overland runoff and base flow.

c (Recharge to saturation zone) minus (Losses to aeration zone).

\section{Wells}

Driller's reports for 90 wells in the Sweetwater Valley study area indicate that yield to wells is highly variable. However, most wells in Sweetwater Valley probably are not located at sites hydrologically favorable for obtaining maximum yields. The characteristics of the well that had the maximum reported yield from each geologic formation have been described (table 5). These wells probably do not penetrate the full thickness of the ground-water reservoir and may not define the maximum production of wells in each geologic formation.

\section{Water Quality}

Sweetwater Creek water-quality data were collected by TVA from October 1968 to September 1972. Data were obtained at river mile 16.7 from October 1968 to May 1970, and at river mile 17.6 for the remainder of the period. The results are summarized in table 6 . The samples were collected from the open channel and represent untreated stream water. The analyses undoubtedly reflect sewage effluent from the city of Sweetwater. The maximum 
value for color, chloride, and dissolved solids exceeded the U.S. Environmental Protection Agency (1979) recommended limits for drinking water. However, most values were within those 1 imits.

Table 5.--Description of wells in upper Sweetwater Valley with maximum reported yield from indicated geologic formation

\begin{tabular}{lccrr}
\hline Geologic formation & $\begin{array}{c}\text { Yield } \\
\text { (gal/min) }\end{array}$ & $\begin{array}{l}\text { Specific } \\
\text { capacitya }\end{array}$ & $\begin{array}{l}\text { Rego- } \\
\text { lith } \\
\text { (ft) }\end{array}$ & $\begin{array}{l}\text { Well } \\
\text { depth } \\
\text { (ft) }\end{array}$ \\
\hline Ottosee Shale & 118 & 20 & 30 & 124 \\
Holston Limestone & 12 & .3 & 103 & 110 \\
Lenoir Limestone & 17 & --- & 26 & 330 \\
$\quad$ Lenoir/Mascot contact & 1,360 & 34 & 27 & 178 \\
Mascot Dolomiteb & 23 & --- & 80 & 225 \\
Kingsport Formationb & 14 & --- & 115 & 298 \\
Longview Dolomiteb & 15 & --- & 21 & 125 \\
Chepultepec Dolomite & 110 & 4.2 & 73 & 155 \\
Copper Ridge Dolomite & 100 & --- & 5 & 105 \\
Maynardville Limestone & 20 & --- & 63 & 105 \\
Conasauga Shale & 20 & .4 & 90 & 95 \\
\hline
\end{tabular}

a Yield per foot of drawdown in the pumped well.

b Former usage, see table 1 .

\section{BASE-FLOW ANALYSIS}

\section{Base-Flow Measurements}

Streams in carbonate terrane can lose flow to the ground-water system along some reaches through solution openings in the stream channel when the stream level is above ground-water level. This water can return to the stream system by springs and seeps downstream from the area of water loss or in an adjacent stream basin where the ground-water level is above stream leve1. Through this process, various reaches of a stream channel lose or gain water. A stream can be deficient in flow or completely dry if groundwater levels are below stream level and solution openings beneath the stream are large and extensive enough to divert streamflow underground, thus draining the area by subsurface routes.

Low base-flow measurements and high base-flow measurements of Sweetwater Creek and tributaries were made during the study. Significant changes in flow per mile of channel were detected by both periods of measurements. Gains or losses of flow along the channel can be attributed to one or more of the following: measurement error, evaporation, unmeasured tributary inflow, diversions, or interaction with the ground-water system. No diversion of flow by the city of Sweetwater occurred during either period of measurements. Amounts of flow diversion by industry or 
other users are unknown. Most, if not all, of the flow changes are assumed to have been caused by water leaving or entering the stream through solution openings in the bedrock. The magnitude of the flow change is indicative of the relative interaction between the surface and the ground-water systems under base-flow conditions.

Table 6.--Range in water-quality parameters from Sweetwater Creek; samples obtained October 1968 to September 1972 (analyses by Tennessee Valley Authority)

\begin{tabular}{|c|c|c|c|c|c|}
\hline Constituent & $\begin{array}{c}\text { Number } \\
\text { of } \\
\text { Deter- } \\
\text { ninations }\end{array}$ & $\begin{array}{c}\text { Minimum } \\
\text { value }\end{array}$ & $\begin{array}{c}\text { Maximum } \\
\text { value }\end{array}$ & $\begin{array}{r}\text { Median } \\
\text { value }\end{array}$ & $\begin{array}{c}\text { EPA } \\
1 \text { imit }\end{array}$ \\
\hline Alkalinity $\left(\mathrm{mg} / \mathrm{L}\right.$ as $\left.\mathrm{CaCO}_{3}\right)$ & 25 & 78 & 151 & 130 & $-\ldots$ \\
\hline Bicarbonate $\left(\mathrm{mg} / \mathrm{L}\right.$ as $\left.\mathrm{HCO}_{3}\right)$ & 25 & 95 & 184 & 158 & -- \\
\hline Calcium, dissolved ( $\mathrm{mg} / \mathrm{L}$ as $\mathrm{Ca}$ ) & 25 & 24 & 44 & 35 & --- \\
\hline Carbon dioxide, dissolved (mg/L as $\left.\mathrm{CO}_{2}\right)$ & 4 & 6.5 & 13 & 10 & --- \\
\hline Ch loride, dissolved ( $\mathrm{mg} / \mathrm{L}$ as $\mathrm{Cl})$ & 25 & 4.0 & 260 & 36 & $a_{2} 50$ \\
\hline Color (platinum cobalt units) & 25 & 2 & 60 & 6 & $\mathbf{a}_{15}$ \\
\hline Hardness, noncarbonate $\left(\mathrm{mg} / \mathrm{L}\right.$ as $\left.\mathrm{CaCO}_{3}\right)$ & 25 & 1 & 17 & 10 & --- \\
\hline Hardness ( $\mathrm{mg} / \mathrm{L}$ as $\mathrm{CaCO}_{3}$ ) & 25 & 91 & 158 & 134 & -- \\
\hline Iron, total recoverable ( $\mu \mathrm{g} / \mathrm{L}$ as $\mathrm{Fe}$ ) & 25 & 60 & 360 & 150 & a 300 \\
\hline Magnesium, dissolved (mg/L as $\mathrm{Mg}$ ) & 25 & 6.9 & 16 & 12 & -- \\
\hline Nitrogen, ammonia dissolved (mg/L as $\mathrm{N}$ ) & 18 & .03 & 1.9 & .17 & --- \\
\hline Nitrogen, nitrate dissolved (mg/L as $\mathrm{N}$ ) & 18 & .24 & 1.8 & 1.1 & $\mathrm{~b}_{10}$ \\
\hline Nitrogen, nitrite dissolved (mg/L as $N$ ) & 18 & .01 & .14 & .05 & --- \\
\hline Nitrogen, organic total (mg/L as $\mathrm{N})$ & 17 & .10 & 1.1 & .41 & --- \\
\hline $\mathrm{pH}$ (units) & 24 & 6.9 & 7.8 & 7.3 & $a_{6.5}-8.5$ \\
\hline Phosphorus, tota 1 (mg/L as P) & 18 & .06 & 1.2 & .28 & -- \\
\hline Potassium, dissolved ( $\mathrm{mg} / \mathrm{L}$ as $\mathrm{K}$ ) & 25 & 1.2 & 7.1 & 2.1 & --- \\
\hline Silica, dissolved $\left(\mathrm{mg} / \mathrm{L}\right.$ as $\left.\mathrm{SiO}_{2}\right)$ & 25 & 5.3 & 7.6 & 6.3 & --- \\
\hline Sodium, dissolved ( $\mathrm{mg} / \mathrm{L}$ as $\mathrm{Na}$ ) & 25 & 1.6 & 180 & 22 & --- \\
\hline Sodium adsorption ratio & 25 & .1 & 6.3 & .9 & --- \\
\hline Sodium percent & 25 & 3 & 71 & 29 & --- \\
\hline Solids, dissolved residue ( $180^{\circ} \mathrm{C}(\mathrm{mg} / \mathrm{L})$ & L) 24 & 117 & 628 & 198 & a 500 \\
\hline Specific conductance (umho) & 25 & 175 & 1110 & 315 & -- \\
\hline Sulfate, dissolved $\left(\mathrm{mg} / \mathrm{L}\right.$ as $\left.\mathrm{SO}_{4}\right)$ & 25 & 2.7 & 26 & 8.2 & a 250 \\
\hline Temperature $\left({ }^{\circ} \mathrm{C}\right)$ & 24 & 1.0 & 23.5 & 16 & --- \\
\hline
\end{tabular}

a Secondary maximum contaminant level (U.S. Environmental Protection Agency, 1979).

b Primary maximum contaminant leve1 (U.S. Environmental Protection Agency, 1976).

A preliminary reconnaissance of the stream system was made on September $28,29,1981$, at which time many observations of dry channel were made. The first set of measurements of Sweetwater Creek (flow, temperature, and specific conductance) was made by the U.S. Geological Survey October 15, 1981, during low base flow (table 7 and fig. 4). Additional flow measurements were obtained October 20, 1981, to better define parts of the flow system. Streamflow was measured at 42 sites on Sweetwater Creek and its 
Table 7.--Low base-flow data (October 15 and 20, 1981)

\begin{tabular}{|c|c|c|c|c|c|c|}
\hline $\begin{array}{l}\text { Site } \\
\text { No. }{ }^{2}\end{array}$ & $\begin{array}{l}\text { Station } \\
\text { No. }\end{array}$ & Date & Time & $\begin{array}{l}\text { Temper- } \\
\text { a ture } \\
\left({ }^{\circ} \mathrm{C}\right)\end{array}$ & $\begin{array}{l}\text { Stream- } \\
\text { flow, } \\
\text { instan- } \\
\text { taneous } \\
\left.\text { (ft } \mathrm{ft}^{3} / \mathrm{s}\right)\end{array}$ & $\begin{array}{l}\text { Spe- } \\
\text { cific } \\
\text { con- } \\
\text { duct- } \\
\text { ance } \\
\text { (umho) }\end{array}$ \\
\hline $\bar{b}_{1}$ & $03520040^{\circ}$ & & 1620 & 15.0 & 0.78 & 280 \\
\hline 2 & 03520041 & & 0910 & 15.5 & 4.3 & 260 \\
\hline 3 & 03520043 & & 0950 & 14.5 & 7.2 & 305 \\
\hline 4 & 03520044 & & 0830 & 15.5 & 7.2 & 332 \\
\hline$c_{5}$ & 03520045 & & 1055 & 14.5 & 7.1 & 345 \\
\hline$c_{6}$ & 03520050 & & 1015 & 15.5 & 9.0 & 321 \\
\hline 7 & 03520053 & $>$ oct. $15,1981<$ & 1330 & 15.5 & 2.1 & 285 \\
\hline$b_{9}$ & 353247084291400 & & 1115 & 15.0 & .17 & 232 \\
\hline 12 & 353250084291400 & & 1250 & 15.5 & .15 & 230 \\
\hline 14 & 353256084291900 & & 1405 & 15.5 & .74 & 232 \\
\hline 15 & 353258084292600 & & 1500 & 14.0 & .33 & 245 \\
\hline 18 & 353302084304700 & & 1235 & 14.0 & .00 & 345 \\
\hline 23 & 353324084305900 & & 1330 & 14.0 & .02 & 250 \\
\hline 25 & $353355084301500]$ & & 1415 & 15.0 & .17 & 300 \\
\hline 26 & 353358084295300 & Oct. 20,1981 & 1115 & 15.0 & 1.2 & 183 \\
\hline \multirow[t]{2}{*}{27} & 353409084300000 & Oct. 15,1981 & 1615 & 16.5 & .85 & 270 \\
\hline & & Oct. 20,1981 & 1150 & -- & .94 & -- \\
\hline$b_{28}$ & 353416084290100 & Oct. 15,1981 & 1515 & 15.5 & .06 & 345 \\
\hline \multirow[t]{2}{*}{30} & 353431084291300 & Oct. 15,1981 & 1430 & 16.0 & 3.0 & 255 \\
\hline & & Oct.20,1981 & 1315 & -- & 2.9 & -- \\
\hline 31 & 3534480842843007 & & {$[1330$} & 14.5 & .05 & 340 \\
\hline 32 & 353503084281400 & & 1215 & 14.0 & .11 & 405 \\
\hline 33 & 353503084281600 & & 1140 & 15.0 & 3.4 & 260 \\
\hline 34 & 353508084275700 & & 1615 & 15.5 & .68 & 290 \\
\hline 35 & 353525084282200 & & 1650 & 17.0 & 1.0 & 320 \\
\hline 36 & 353536084281200 & & 0905 & 15.5 & 1.0 & 292 \\
\hline 37 & 353539084272900 & & 1435 & 15.5 & .21 & 370 \\
\hline 39 & 353544084290100 & & 1635 & 20.5 & .02 & 281 \\
\hline 42 & 353546084292200 & & 1600 & 20.0 & .08 & 350 \\
\hline 43 & 353546084292300 & & 1600 & 20.5 & .04 & 344 \\
\hline 44 & 353549084280800 & & 0730 & 14.5 & 5.7 & 290 \\
\hline 45 & 353550084280500 & Oct. $15,1981<$ & 0845 & 14.5 & 6.5 & 280 \\
\hline 46 & 353551084274700 & & 0750 & 15.0 & 6.3 & 300 \\
\hline 47 & 353553084273500 & & 1305 & 16.0 & .24 & 370 \\
\hline 48 & 353555084273200 & & 1105 & 14.5 & .10 & 420 \\
\hline 49 & 353601084272600 & & 0850 & 14.5 & 8.0 & 300 \\
\hline 51 & 353653084270100 & & 0915 & 14.5 & .19 & 365 \\
\hline 53 & 353714084265100 & & 1005 & 14.0 & .04 & 290 \\
\hline 54 & 353750084251600 & & 1445 & 15.0 & .23 & 295 \\
\hline 57 & 353800084263300 & & 1830 & 15.0 & 1.2 & 250 \\
\hline 58 & 353828084255100 & & 1145 & 15.0 & 2.4 & 290 \\
\hline 59 & 353830084261100 & & 0830 & 15.0 & 8.4 & 315 \\
\hline 60 & 353831084260900 & & 0915 & 14.0 & .65 & 320 \\
\hline 62 & 353858084254100 & & L1040 & 15.0 & 11 & 320 \\
\hline
\end{tabular}


tributaries. Stream channels were dry at 43 other sites. The flow at the gage on Sweetwater Creek below Sweetwater was $7.1 \mathrm{ft}^{3} / \mathrm{s}$, which roughly corresponds to the lowest average daily flow $\left(7.3 \mathrm{ft}^{3} / \mathrm{s}\right)$ expected once in 5 years (table 3 ).

The second set of measurements was made by the Survey February 23, 24, 1982, during high base flow (table 8 and fig. 5). The flow at the gage on Sweetwater Creek below Sweetwater was $68 \mathrm{ft}^{3} / \mathrm{s}$, which is roughly $10 \mathrm{times}$ more than the flow on October 15 and about 36 percent greater than the average discharge for the period of gaging record. Streamflow was measured at 58 sites on Sweetwater Creek and its tributaries. Stream channels were dry at 12 other sites.

The gains and losses per mile of channel reach for both sets of measurements were computed and plotted on maps (figs. 4 and 5). The gaining and losing channel reaches defined by low base-flow measurements showed the difficulty in locating optimum streamflow diversion sites in the carbonate terrane of the Valley and Ridge. Combined stream and spring flow for October 15, 1981, was $6.5 \mathrm{ft}^{3} / \mathrm{s}$ at river mile 21.5 (fig. 4). Slightly farther downstream at river mile $20.7,8.0 \mathrm{ft}^{3} / \mathrm{s}$ (an increase of 23 percent) was available. However, no further flow increases were detected until river mile 16.7 where $9.0 \mathrm{ft}^{3} / \mathrm{s}$ was measured. Significant tributary inflow originating at major springs resulted in flow increase to $11.4 \mathrm{ft}^{3} / \mathrm{s}$ at river mile 15.1 .

\section{Areas of Surplus and Deficient Flow}

Although there is little or no interbasin transfer of water out of the Sweetwater Valley, the discharge measurements showed interbasin transfer among the sub-basins of the valley. The discharge data were analyzed in the following manner:

- The average flow per unit area of surface drainage for the entire study area was computed based on the total basin flow and basin area at the most downstream site.

- The surface drainage divides between all streamflow measurement sites were delineated, and the surface area of each sub-basin was computed.

- The area of each sub-basin was multiplied by the average flow per unit area of surface drainage to determine the outflow expected from each sub-basin.

- The actual outflow from each sub-basin was calculated then compared to the expected outflow to define areas with surplus or deficient flow.

The areas of surplus and deficient flow as derived by this procedure were identified and plotted on maps (figs. 6 and 7). In general, topographically higher areas have deficient outflow unless significant springflow occurs in the basin. Topographically lower areas adjacent to the main channel of Sweetwater Creek generally have surplus flow. Major flow surpluses were generally associated with basins in which the majority of flow originated at springs. 


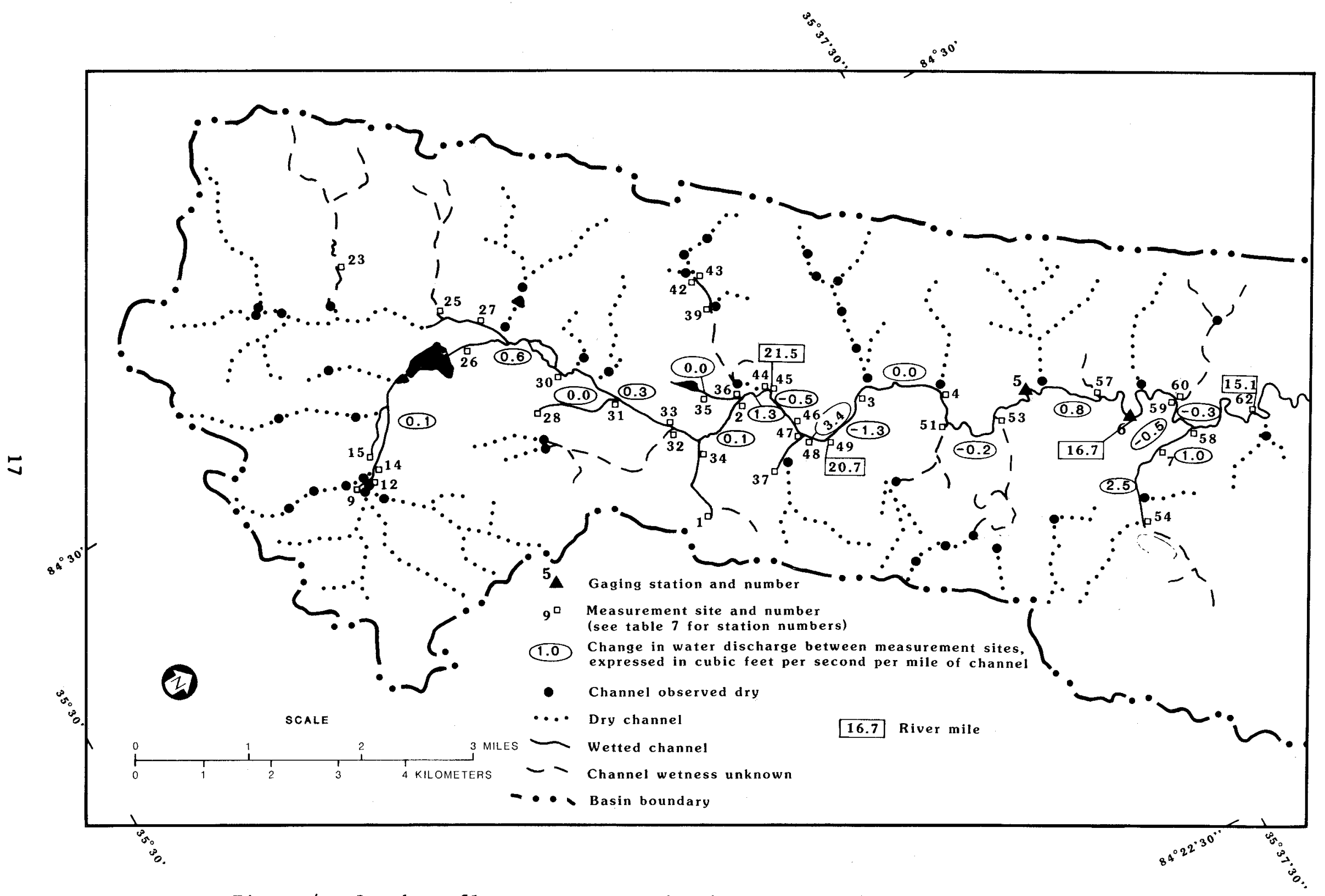

Figure 4.--Low base-flow measurement site locations, and change in water discharge between sites, October 15-20, 1981 . 
Table 8.--High base-flow data

(February 23-24, 1982)

\begin{tabular}{|c|c|c|c|c|c|c|}
\hline $\begin{array}{l}\text { Site } \\
\text { No.a }\end{array}$ & $\begin{array}{c}\text { Station } \\
\text { No. }\end{array}$ & Date & Time & $\begin{array}{l}\text { Temper- } \\
\text { ature } \\
\left({ }^{\circ} \mathrm{C}\right)\end{array}$ & $\begin{array}{l}\text { Stream- } \\
\text { flow, } \\
\text { instan- } \\
\text { taneous } \\
\left(\mathrm{ft}^{3} / \mathrm{s}\right)\end{array}$ & $\begin{array}{l}\text { Spe- } \\
\text { cific } \\
\text { con- } \\
\text { duct- } \\
\text { ance } \\
\text { (גmho) }\end{array}$ \\
\hline${ }_{1}$ & 035200407 & & 1305 & 14.0 & 5.5 & 200 \\
\hline 2 & 03520041 & & 0825 & 9.0 & 39 & 203 \\
\hline 3 & $03520043>$ & Feb. 23, 1982 & 1010 & 9.5 & 55 & 228 \\
\hline 4 & 03520044 & & 0830 & 8.5 & 59 & 240 \\
\hline$c_{5}$ & $03520045]$ & & $\lfloor 1020$ & 9.5 & 68 & 230 \\
\hline 7 & 03520053 & & {$[0945$} & 13.0 & 10 & 265 \\
\hline 8 & 353244084310500 & & 1215 & 12.5 & 1.0 & 200 \\
\hline$b_{9}$ & 353247084291400 & & 1000 & 14.0 & .83 & 180 \\
\hline 10 & 353249084291200 & & 0900 & 11.5 & .04 & 166 \\
\hline 11 & 353249084291300 & & 0905 & 13.0 & 4.2 & 163 \\
\hline 13 & 353250084291600 & & 0915 & -- & .01 & 172 \\
\hline$b_{15}$ & 353258084292600 & & 1220 & 13.0 & 1.5 & 126 \\
\hline 16 & $353300084294800\}$ & Feb.24, 1982< & 1140 & 14.5 & .73 & 172 \\
\hline 17 & 353300084301800 & & 1145 & 14.0 & .04 & 145 \\
\hline 18 & 353302084304700 & & 0800 & 11.0 & 4.0 & 210 \\
\hline 19 & 353314084294500 & & 1315 & 14.5 & 2.5 & 182 \\
\hline 20 & 353315084294400 & & 1350 & 15.0 & 8.1 & 186 \\
\hline 21 & 353315084305100 & & 0845 & 10.0 & 3.5 & 130 \\
\hline 22 & 353322084295700 & & 1420 & 16.0 & .14 & 170 \\
\hline 24 & 353339084302800 & & 0940 & 11.0 & 8.5 & 190 \\
\hline 25 & 353355084301500 & & 1045 & -- & 2.0 & -- \\
\hline 26 & 353358084295300 & & {$[1410$} & 11.5 & 11 & 160 \\
\hline 27 & 353409084300000 & & 1235 & 11.0 & 13 & 198 \\
\hline$b_{28}$ & 353416084290100 & & 1320 & 14.5 & .55 & 295 \\
\hline 29 & 353420084295100 & $>\mathrm{Feb} .23,1982<$ & 1500 & 10.5 & 1.5 & 122 \\
\hline 30 & 353431084291300 & & 1200 & 9.5 & 29 & 200 \\
\hline 31 & 353448084284300 & & 1235 & 12.0 & .87 & 285 \\
\hline 32 & 353503084281400 & & 1120 & 13.0 & 1.5 & 315 \\
\hline 33 & $353503084281600]$ & & 1030 & 9.0 & 32 & 195 \\
\hline
\end{tabular}

See footnotes at end of table. 
Table 8.--High base-f low data--Continued

(February 23-24, 1982)

\begin{tabular}{|c|c|c|c|c|c|c|}
\hline $\begin{array}{l}\text { Site } \\
\text { No. a }\end{array}$ & $\begin{array}{c}\text { Station } \\
\text { No. }\end{array}$ & Da te & Time & $\begin{array}{l}\text { Temper- } \\
\text { a ture } \\
\left({ }^{\circ} \mathrm{C}\right)\end{array}$ & $\begin{array}{l}\text { Stream- } \\
\text { flow, } \\
\text { instan- } \\
\text { taneous } \\
\left(\mathrm{ft}^{3} / \mathrm{s} \text { ) }\right.\end{array}$ & $\begin{array}{l}\text { Spe- } \\
\text { cific } \\
\text { con- } \\
\text { duct- } \\
\text { ance } \\
\text { (umbo) }\end{array}$ \\
\hline 34 & 3535080842757007 & & 1215 & 15.0 & 6.3 & 216 \\
\hline 35 & 353525084282200 & Feb.23, 1982 & 1455 & 17.0 & 5.0 & 242 \\
\hline 36 & 353536084281200 & & 0900 & 8.5 & 4.6 & 272 \\
\hline 38 & 353539084282000 & & 1405 & 14.0 & 3.3 & 178 \\
\hline 39 & 353544084290100 & & 0805 & 11.5 & 2.3 & 160 \\
\hline$b_{40}$ & 353544084292500 & & 1020 & 10.5 & .05 & 38 \\
\hline 41 & 353545084290100 & Feb.24, 1982 & 0720 & 11.0 & .39 & 220 \\
\hline 42 & 353546084292200 & & 0950 & 11.0 & .57 & 146 \\
\hline 43 & 353546084292300 & & 0900 & 10.5 & .60 & 97 \\
\hline 44 & 353549084280800 & & $=0800$ & 8.5 & 51 & 208 \\
\hline 45 & 353550084280500 & & 0850 & 8.5 & 51 & 208 \\
\hline 46 & 353551084274700 & & 0735 & 9.5 & 54 & 215 \\
\hline 47 & 353553084273500 & Feb.23, 1982 & 1220 & 15.5 & 1.6 & 270 \\
\hline 48 & 353555084273200 & & 1245 & 13.5 & .43 & 340 \\
\hline 49 & 353601084272600 & & 0900 & 9.0 & 54 & 220 \\
\hline 50 & 353631084274300 & & 1115 & 10.0 & 1.2 & 124 \\
\hline 51 & 353653084270100 & & 0920 & 12.5 & 1.5 & 395 \\
\hline 52 & 353713084263200 & Feb.24, 1982 & 1415 & -- & 4.6 & -- \\
\hline \multirow[t]{2}{*}{53} & 353714084265100 & Feb.23, 1982 & 1020 & 11.5 & 4.2 & 285 \\
\hline & & Feb. 24, 1982 & 1345 & 15.5 & 4.2 & 290 \\
\hline 54 & 353750084251600 & Feb.24, 1982 & 1025 & 13.5 & 1.8 & 302 \\
\hline 55 & 353757084264300 & Feb.23, 1982 & 1500 & 14.0 & 5.8 & 200 \\
\hline 56 & 353759084245500 & Feb.24, 1982 & 1100 & 14.0 & 1.3 & 300 \\
\hline 57 & 353800084263300 & & 1530 & 14.0 & 5.9 & 207 \\
\hline 58 & 353828084255100 & & 1335 & 14.5 & 9.0 & 255 \\
\hline 59 & 353830084261100 & Feb.23,1982 & 0905 & 9.0 & 74 & 240 \\
\hline 60 & 353831084260900 & & 0945 & 12.0 & 1.9 & 203 \\
\hline 61 & 353858084252800 & & 1410 & 16.5 & .24 & 310 \\
\hline 62 & 353858084254100 & & 1205 & 10.0 & 84 & 240 \\
\hline 63 & 353900084270100 & Feb. 24, 1982 & 1200 & -- & .05 & -- \\
\hline
\end{tabular}

a site numbers are referenced to figure 5 .

b spring.

c stream gaging station. 


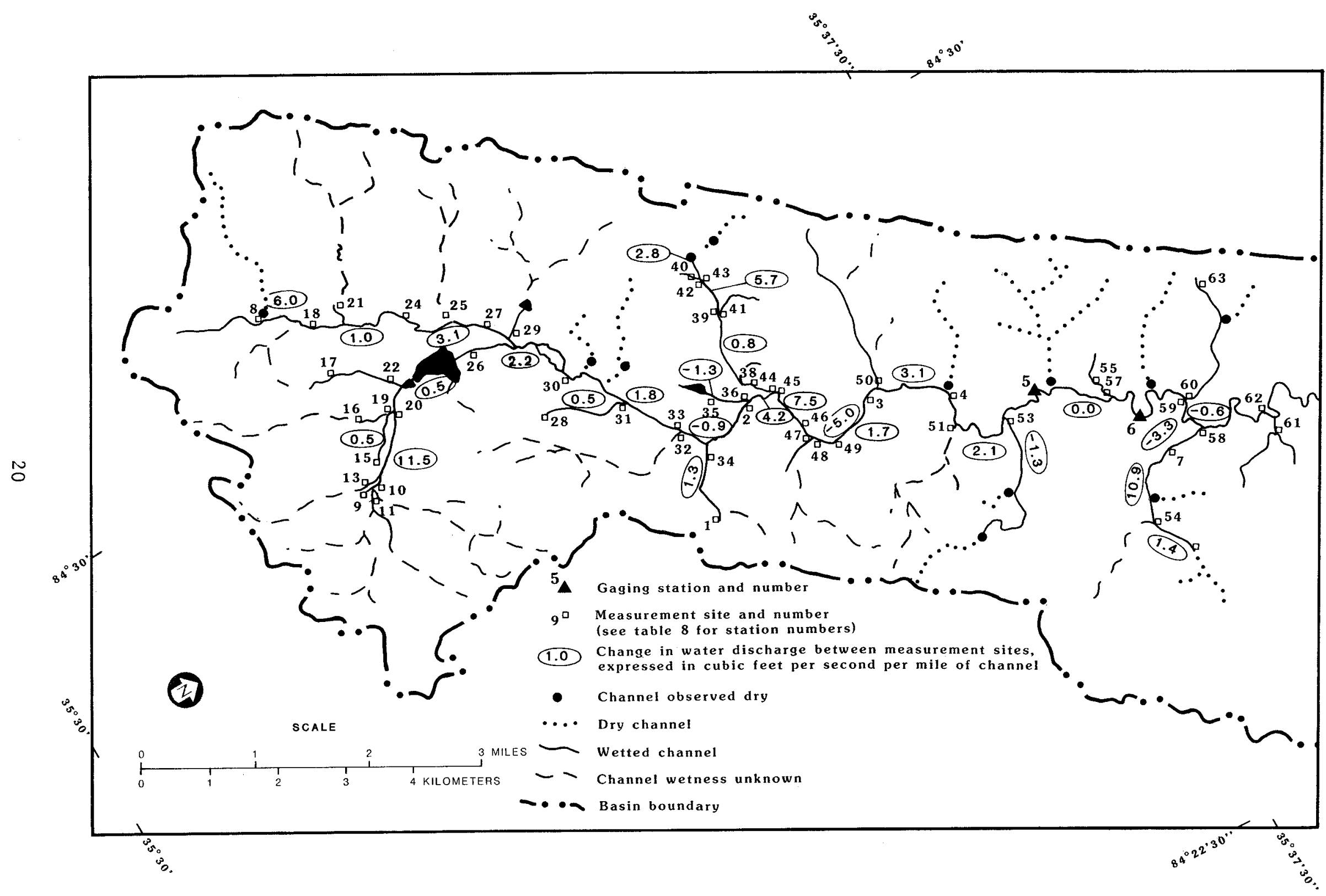

Figure 5.--High base-flow measurement site locations, and change in water discharge between sites, February 23-24, 1982. 


\title{
CONCEPTS OF GROUND-WATER FLOW
}

\author{
Previous Investigations
}

The distribution of streamflow in upper sweetwater Valley indicates a ground-water flow network which has many similarities to two other areas previously studied by the U.S. Geological Survey. The two areas, Dandridge and Savannah Valley, are both in the Valley and Ridge physiographic province. Sweetwater Valley is about midway between the two areas. Results and conclusions from both reports were used as guides for development of a ground-water flow concept for the Sweetwater Valley.

In Dandridge, Tennessee, the concept of the ground-water flow system proposes that there is regionally diffuse flow across the strike of the beds towards topographically low areas. This flow may be intercepted by high permeability beds adjacent to the Copper Ridge Dolomite-Chepultepec Dolomite contact and then routed along the strike to springs.

In Savannah Valley, Tennessee, the most productive aquifers were near the top of the Knox Group. Wells with the greatest yields were located on linear features formed by southeasterly trending stream valleys. The linear features are probably the surficial expression of zones or lines of rock fracture or jointing; perhaps fault traces. Being less resistant to subaerial erosion, these zones are prone to form stream valleys which concentrate both surface and underground drainage.

\section{Upper Sweetwater Valley System}

The gaining and losing channel reaches and areas of surplus and deficient flows, determined from discharge measurements (February 23, 24, 1982), were related to the geologic framework. The objective of this analysis was to relate probable groundwater recharge areas to approximate paths of flow to discharge areas. A theoretical ground-water flow concept of the Upper Sweetwater Valley is presented in figure 8.

Regionally, there is probably diffuse flow of ground water across the strike of the formations to topographically low areas. The diffuse flow is evidenced by surface-flow deficiencies in the topographically higher valley perimeter and by surplus surface-flow along the topographically lower central axis of the valley (see figs. 6 and 7). Ground-water flow is generally perpendicular to the strike of the formations and follows irregular flow paths provided by bedding planes, fractures in the rock, and solution-enlarged passages.

The flow of the major springs in the upper Sweetwater valley (springs $4,5,7,9$, and 11 , fig. 8) is supplied by diffuse flow which enters areas of high permeability and reroutes along the strike toward the northeast. 


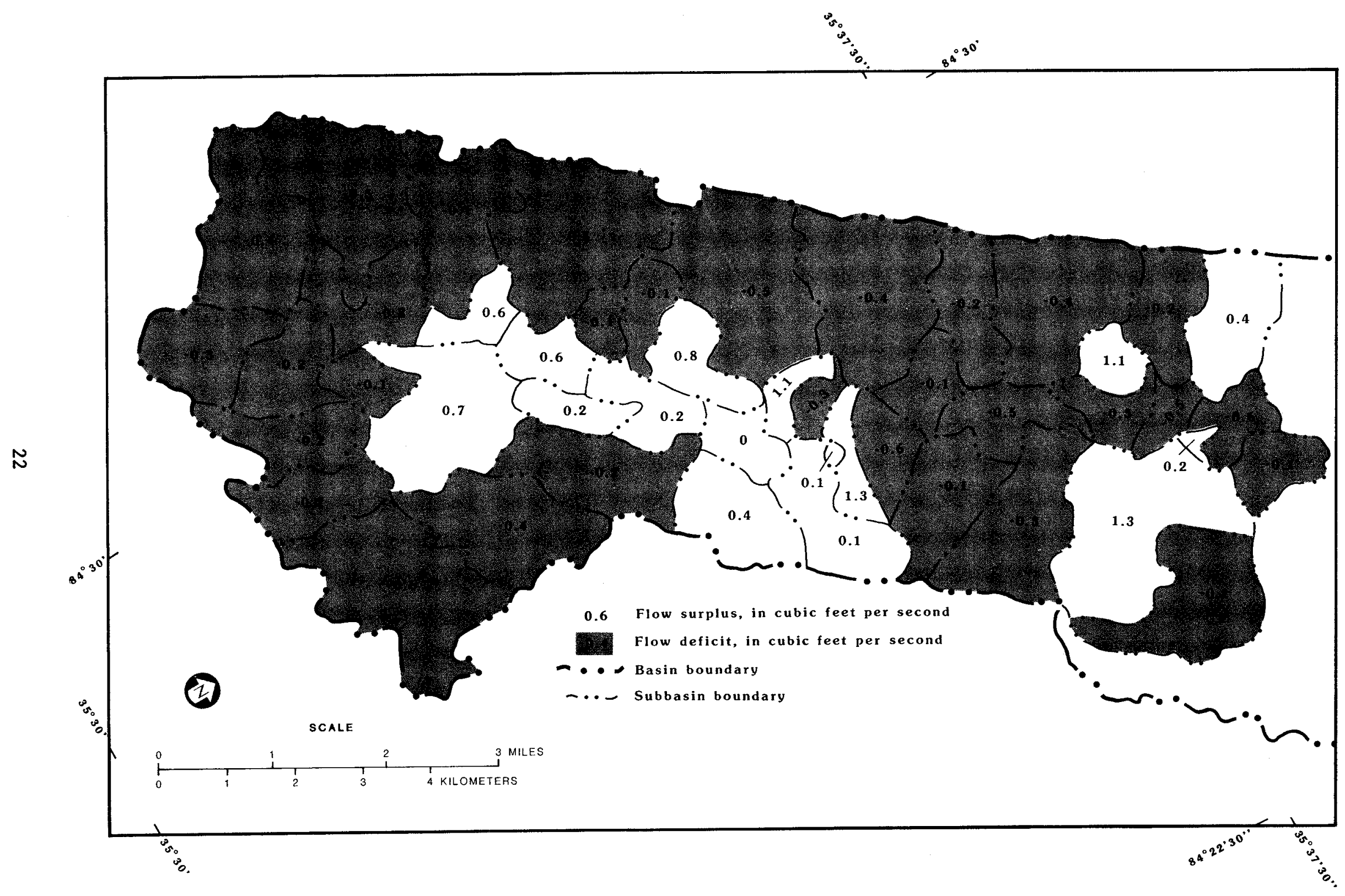

Figure 6.--Areas of surplus and deficient flows in upper Sweetwater Valley, October 15-20, 1981. 


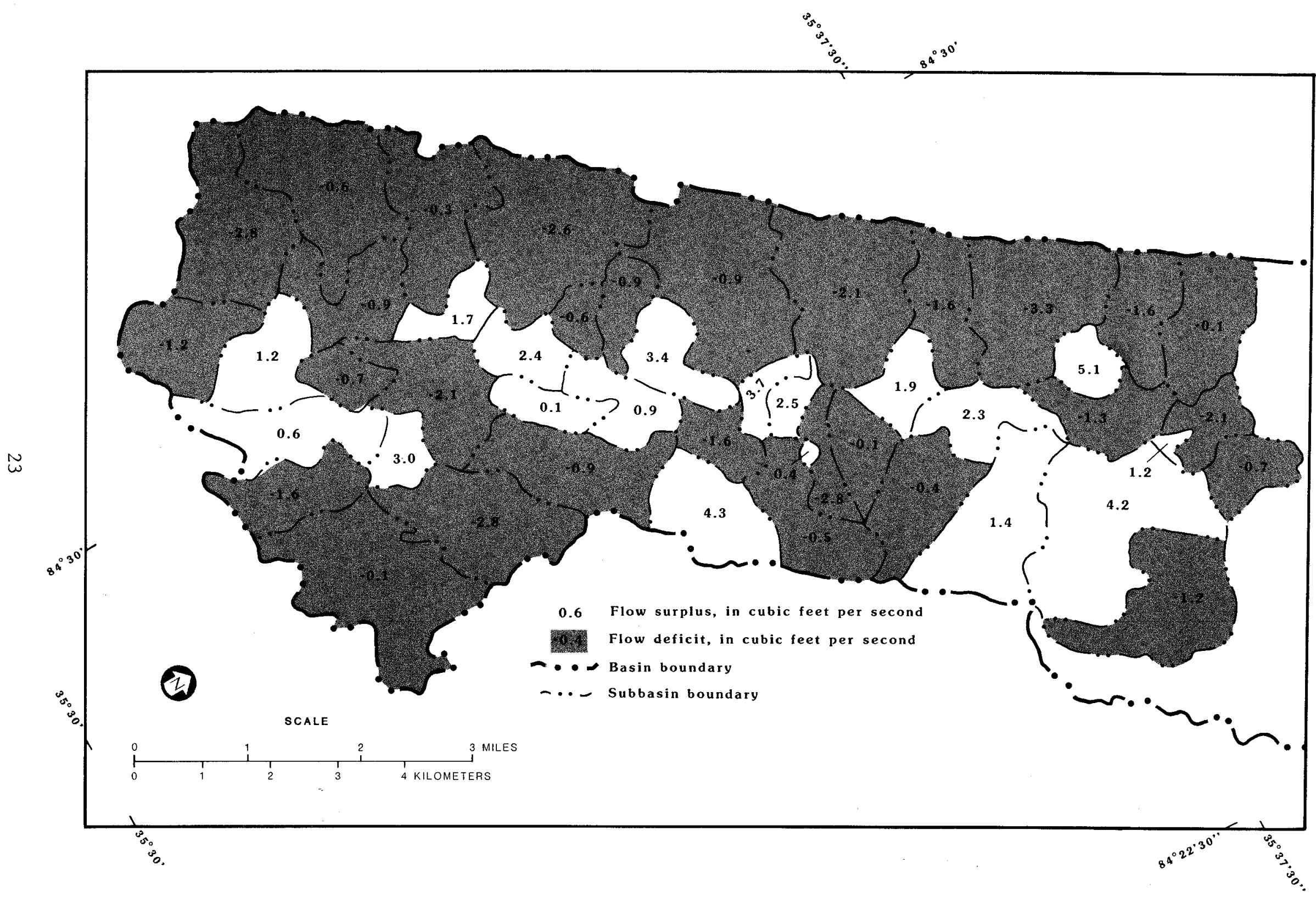

Figure 7.--Areas of surplus and deficient flows in upper Sweetwater Valley, February $23-24,1982$. 
The major ground-water discharge for the northwestern half of the upper Sweetwater Valley occurs at springs in the Knox Group. As in Savannah Valley, the Knox Group is considered to have favorable water producing units. These units (Mascot Dolomite and Longview Dolomite, of former usage) collect the flow, forming systems somewhat comparable to surfacestream systems, and route the ground-water drainage parallel to strike to major springs (springs 4, 5, and 9, fig. 8).

Ground water in the southeastern half of the upper Sweetwater Valley encounters shale as it flows perpendicular to strike toward topographic lows. Shale is relatively impervious and acts as a barrier to water movement. The upgradient rock is usually a carbonate which may or may not have developed increased permeability by solutioning. If the upgradient rock does not have high permeability or secondary porosity, the flow will discharge at relatively small springs at the contact (for example, springs 2 and 12 , fig. 8). If the upgradient rock has high permeability or secondary porosity along the shale contact, the ground water moves along the shale contacts to major discharge sites such as Kilpatrick Spring (spring 7, fig. 8). In areas where the shale formations pinch-out, the water is able to continue flowing across strike. Where this occurs, the flow may be collected by higher permeability formations and routed parallel to strike to major discharge sites. This situation may occur at the unnamed spring (spring 11) in the northeastern-most part of the valley.

Although 1 ittle interbasin ground-water transfer was indicated by runoff comparison, the volume of surplus flow at Kilpatrick spring indicates that some recharge may be coming from the Copper Ridge Dolomite southeast of the surface-water divide. This is probably an insignificant contribution to total valley outflow.

\section{POTENTIAL SOURCES OF WATER SUPPLY}

\section{Site Selection}

A large perennial spring or actively gaining channel reach is a point of major ground-water discharge and may indicate extensive solutioning in the area. These areas of solution act as water-collection systems comprising underground reservoirs (Hollyday and Goddard, 1979). The most productive ground-water reservoirs are probably in the areas up-gradient of the natural ground-water discharge areas. Potential ground-water supply areas in the upper Sweetwater Valley were located on this basis (fig. 9).

Areas have a greater probability for successful development of highyielding ground-water supplies if selected on the basis of hydrologic and geologic criteria. The criteria for selection of high-yielding groundwater areas in the upper Sweetwater Valley are similar to those used in Dandridge and Savannah Valley. In Dandridge, site-selection criteria developed for locating successful ground-water supplies were (1) near a large spring, (2) near a creek that is intermittant, and (3) on or near the contact between the Copper Ridge Dolomite and Chepultepec Dolomite 


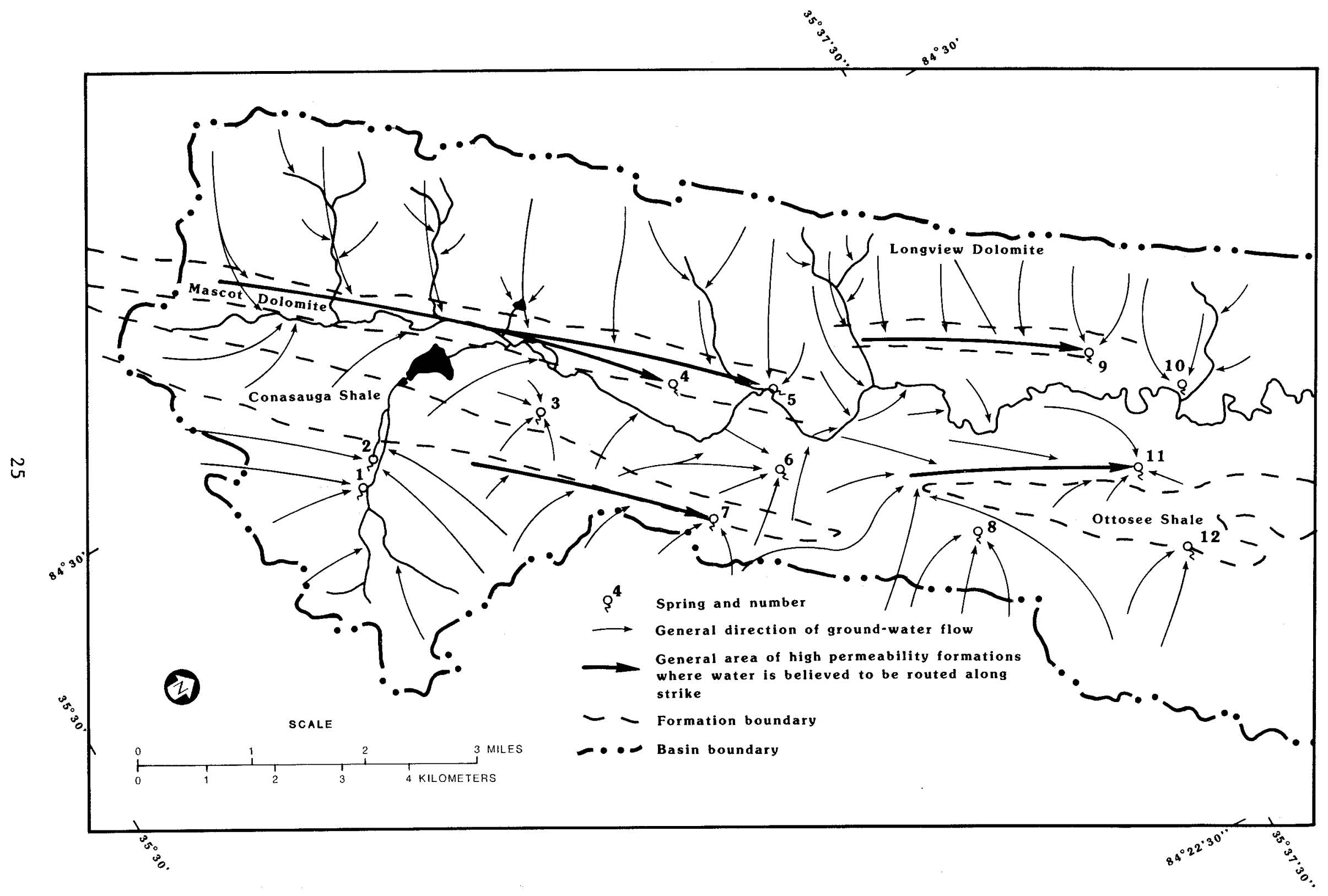

Figure 8.--Theoretical ground-water flow network of upper Sweetwater Valley, February 23-24, 1982. 


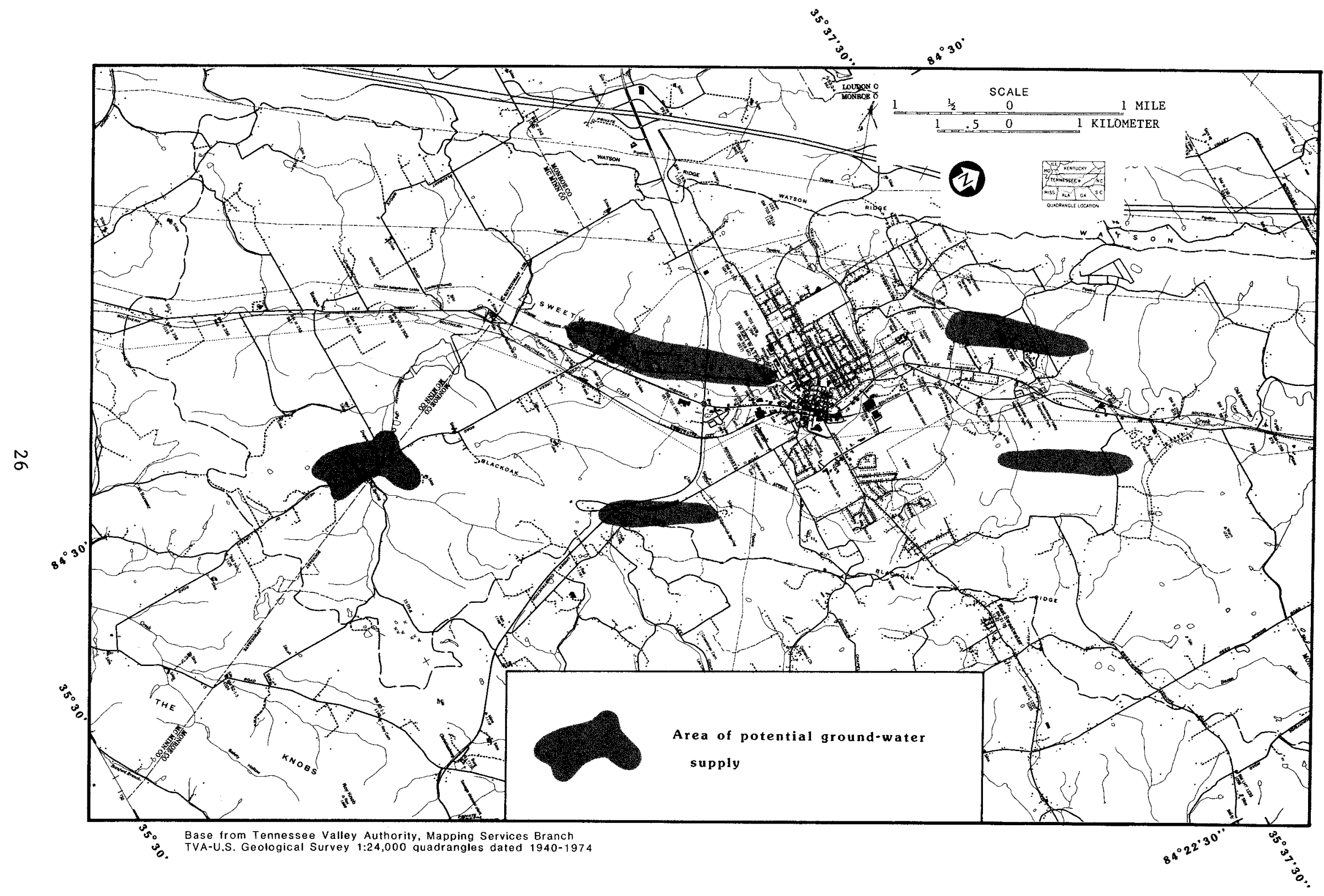

Figure 9.--Potential groundwater supply areas in upper Sweetwater Valley. 
(Hollyday and Goddard, 1979). In Savannah Valley, the principal criterion for locating successful groundwater supplies was the presence of a linear feature formed by a stream valley observable on low-altitude areal photography (Rima, 1974).

As stated previously, the areas which probably have the greatest potential for high ground-water yield are near large perennial springs. Within these areas, the water-bearing characteristics of the rock formations should be considered. Major groundwater flow occurs mainly in underground channel systems which parallel formations of higher permeability, as opposed to lesser diffused flow which traverses formations of different permeabilities. The chance of intercepting one of the underground channel systems increases if a formation with high permeability is tapped.

Sites on or near linear features observable on low-altitude areal photography would have a greater possibility of intercepting a high yielding water zone. These linear features may indicate fractures in the bedrock or solution channels that concentrate ground-water flow. The intersection of two or more linear features would probably be most favorable. Linear trends of topographic features, soil tone, and vegetation from aerial photography were used to identify areas most favorable for ground-water exploration (fig. 10).

\section{Resource Protection}

Some water in carbonate terrane moves through open conduits and may not receive the natural filtration such as is associated with sand and grave 1 aquifers, for example. The water quality in carbonate terrane may be susceptible to pollution and chemical degradation and much of the recharge area may need protection, otherwise the water may need treatment before consumption. Sinkholes, faults, and fractures that may be associated with areas of greater secondary permeability are the major paths by which the ground-water system is recharged and $c$ an also be polluted. Sinkholes and linear features of the upper Sweetwater Valley were detected from aerial photography (fig. 10).

\section{SUMMARY AND CONCLUSIONS}

Sweetwater Valley is in the Valley and Ridge physiographic province of east Tennessee. The area is underlain by a folded and faulted sequence of approximately 5,000 feet of limestone, dolomite, and shale. The limestone and dolomite are highly soluble and form numerous sinkholes. Most ground water occurs in solution openings rather than in primary pore spaces which are essentially nonexistent in the bedrock.

Hydrograph analysis of Sweetwater Creek showed seasonal variation of recharge to the ground-water flow system. A water budget study indicated that during dry years approximately three-fourths of the annual flow to Sweetwater Creek may be derived from ground-water sources. 


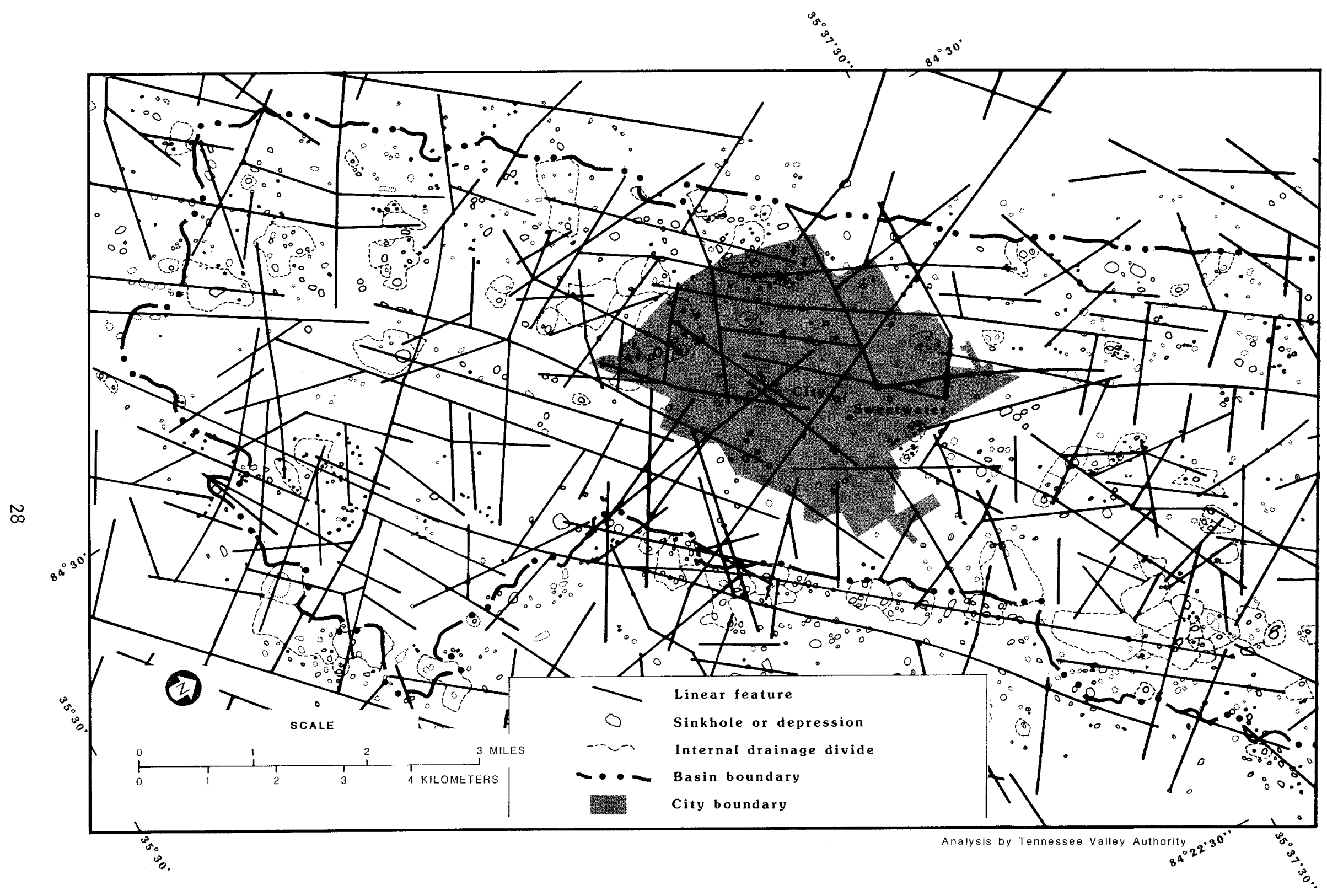

Figure 10.--Locations of sinkholes and linear features from aerial photographic interpretation. 
Two periods of base-flow measurements of Sweetwater Creek identified channel reaches with significant gains and losses of streamflow which indicate an interchange of water between the ground-water and surface-water flow system. Low base-flow stream and spring measurements demonstrated the difficulty in locating optimum streamflow diversion sites in the carbonate terrane of the Valley and Ridge province.

The two periods of base-flow measurements identified areas within the basin having surplus or deficient outflow of ground water. Ground-water flow in upper Sweetwater Valley is believed to be regionally diffuse across formation strikes from the topographically high valley perimeter to the topographically lower areas adjacent to the main stem of Sweetwater Creek. This diffused flow may be interrupted if the water is exposed to a high permeability formation or to an impervious formation. Ground water encountering an impervious formation may discharge at small springs at the contact, or the water may reroute along the contact if the upgradient formation has well developed secondary porosity. Ground water infiltrates the high permeability formations and flows along strike to a major discharge area such as a large perennial spring or actively gaining channel reach. Areas of ground-water flow up-gradient from natural ground-water discharge sites were hypothesized as likely areas for finding significant ground-water reservoirs. The most productive areas are likely to be in the most permeable formations and located on a linear feature.

Ground water in carbonate terrane may be susceptible to degradation unless the recharge area is defined and much of it protected, otherwise the water may require treatment before consumption. 


\section{REFERENCES CITED}

Daniel, J. F., 1976, Estimating groundwater evapotranspiration from streamflow records: Water Resources Research, V. 12, no. 3, p. 360-364.

DeBuchananne, G. D., and Richardson, R. M., 1956, Ground-water resources of East Tennessee: Tennessee Division of Geology Bulletin 58, Part 1, $391 \mathrm{p}$.

Ha 11, W. G., Jackson, B. W., and Love, T. R., 1981, Soil survey of Monroe County, Tennessee: National Cooperative Soil Survey.

Hollyday, E. F., and Goddard, P. L., 1979, Ground-water availability in carbonate rocks of the Dandridge area, Jefferson County, Tennessee: U.S. Geological Survey Water-Resources Investigations Report 79-1263, $50 \mathrm{p}$.

National Oceanic and Atmospheric Administration, 1980, C1imatological data, Tennessee: v. 85, no. 1-13.

Rima, D. R., 1974, Ground water in the Savannah Valley area, Hamilton County, Tennessee: U.S. Geological Survey, Nashville, Tennessee.

Rodgers, John, 1952, Geologic map of the Niota quadrangle, Tennessee: U.S. Coast and Geodetic Survey, U.S. Geological Survey, and Tennessee Valley Authority, scale $1: 24,000$.

Rorabaugh, M. I., 1964, Estimating changes in bank storage and ground-water contribution to streamflow: International Association of Science and Hydrology Publication 63, p. 432-441.

Sun, P-C., Criner, J. H., and Poole, J. L., 1963, Large springs of East Tennessee: U.S. Geological Survey Water-Supply Paper 1755, 52 p.

Swingle, G. D., 1959, Geology, mineral resources, and ground water of the Cleveland area, Tennessee: Tennesee Division of Geology Bulletin 61, 125 p.

Turner, I. L., 1960, Geology along the Saltville Fault, Philadelphia quadrangle, Loudon and Monroe Counties, Tennessee: University of Tennessee Press.

U.S. Environmental Protection Agency, 1976, National interim primary drinking water regulations: U.S. Environmental Protection Agency Report 570/9-76-003, $159 \mathrm{p}$.

U.S. Environmental Protection Agency, 1979, National secondary drinking water regulations: U.S. Environmental Protection Agency Report 570/9-76-000, $37 \mathrm{p}$.

Wyrick, G. G., and Borchers, J. W., 1981, Hydrologic effects of stress-relief fracturing in an Appalachian Valley: U.S. Geological Survey Water-Supply Paper 2177, $51 \mathrm{p}$. 